\title{
IMPACTO DE UNA DIETA CON RESTRICCIÓN DE SODIO Y LÍQUIDOS SOBRE EL ESTADO CLÍNICO DE PACIENTES CON INSUFICIENCIA CARDIACA
}

\section{IMPACT OF A SODIUM AND FLUID RESTRICTED DIET ON CLINICAL STATUS IN HEART FAILURE PATIENTS}

\author{
Eloisa Colín R. (1), Lilia Castillo M. (1), Arturo Orea T. (1), \\ Patricia Montaño H. (1), Joel Dorantes G.(2)
}

\begin{abstract}
(1) Clínica de Insuficiencia Cardíaca del Departamento de Cardiología,
Instituto Nacional de Ciencias Médicas y Nutrición "Salvador Zubirán”, México DF. México.

(2) Departamento de Cardiología del Instituto Nacional de Ciencias Médicas y Nutrición "Salvador Zubirán", México DF. México.
\end{abstract}

\begin{abstract}
Objective: To evaluate the effects of a nutritional intervention focused on the improvement of clinical status and the prognosis of heart failure patients. Methods: A 12-mo randomized controlled study in 203 heart failure (HF) patients assigned to intervention (IG, $n=84)$ or control group $(C G, n=119)$. Patients in the $I G$ received a sodium $(2000$ to $2400 \mathrm{mg} / \mathrm{d})$ and fluid $(<1500 \mathrm{ml} / \mathrm{d})$ restricted diet. CG received general nutritional recommendations. Body composition, clinical status, hospitalization and time of survival were evaluated. Results: At the end of followup, urinary sodium excretion decreased $16,4 \%$ in the IG vs. a $8,8 \%$ increase in the $C G(p<0,05)$. Extracellular water decreased 1,4\% in the IG vs. a 1,2\% increase in the $C G(p=0,03)$. Also, decrease percentage of fatigue was significant and higher in the IG that in the $C G$, and a significant increase in the ejection fraction for the IG $v s$. CG (49,6\% vs. 5,0\%, p=0,001), among systolic HF patients was found. Amount of hospitalizations and time of survival tended to be better in the IG. Conclusion: A nutritional intervention with restriction of sodium and fluid was proved to be beneficial since had positive effects in clinical status in HF patients.
\end{abstract}

Key words: heart failure; nutritional intervention; body composition; survival; extracellular water.

Este trabajo fue recibido el 25 de Mayo de 2010 y aceptado para ser publicado el 20 de Noviembre de 2010.

\section{INTRODUCTION}

The primary nutritional strategies in patients with heart failure (HF) are to accomplish and maintain a good nutritional status with less cardiac stress, and to decrease or prevent sodium and fluid retention in addition to correct cardiac cachexia syndrome or limit its severity. In this sense, the specific recommendations are focused on sodium and fluid restrictions and weight optimization to prevent cardiac descompensation and subsequent hospitalizations in order to decrease hospitalization costs and improve the patient's quality of life. In addition, considering the high prevalence of coronary disease as a cause of HF, it is necessary to decrease intakes of saturated lipids, cholesterol, and simple carbohydrates (1-3).
Dietary sodium intake has become the target for exogenous modulation as facilitated by nutrition prescription. Because of this awareness of the importance of sodium balance in HF, it has been presumed based on empiric knowledge that reducing exogenous sodium intake in an overtly fluid overloaded state would be an appropriate intervention (4).

Both, the American College of Cardiology and American Heart Association (5) and the European Society of Cardiology (6) guidelines for the evaluation and management of patients with HF recommend sodium restriction (2000 $\mathrm{mg}$ daily) in patients with current or prior symptoms of HF who have evidence of fluid retention and fluid restriction ( $<2$ liters per day) 
may be considered in those with persistent or recurrent fluid retention despite sodium restriction and high-dose diuretics, especially with hyponatremia. However, few randomized, controlled trials have been conducted to evaluate specific recommendations related to these restrictions and its long time clinical effects, showing controversial results (7-9). Indeed, the current level of evidence for these recommendations remains being $C$, based on expert opinion.

Moreover, the most available studies in HF patients are focused to restrict only sodium and/or fluids, leaving outside macronutrients consumption $(7,8,10)$.

The purpose of the present study was to evaluate the effects of a nutritional intervention focused on the improvement of clinical status and the prognosis of heart failure patients.

\section{MATERIALS AND METHODS Patients}

This 12-months randomized controlled trial included 203 male and female patients who attended the Heart Failure Clinic at the "Instituto Nacional de Ciencias Médicas y Nutrición Salvador Zubirán" (INCMNSZ) in Mexico City. Patients were recruited if they were 18 years or older, with confirmed diagnosis of HF (defined as decreased systolic and/or diastolic) function as determined by echocardiogram) (5). Subjects were excluded if they already had a specific dietary regimen, renal failure, uncontrolled dysthyroidism, hepatic failure, unstable ischemic heart disease (unstable angina and/or myocardial infarction), recent myocardial revascularization procedures (arterial coronary angioplasty and/ or surgical revascularization in the previous 3 months), severe arrhythmias, HF secondary to chemotherapy, suspicion of malignancy, or limb amputations.

The present study was approved by the institutional ethics committee of biomedical research in humans of the INCMNSZ, and all patients were informed regarding the purpose of the study and signed informed consent forms.

\section{Management protocol}

Subjects were randomized to intervention group (IG, $\mathrm{n}=84)$, or control group (CG, $\mathrm{n}=119)$. Procedure was blinded to the cardiologist who evaluated the clinical status of patients and to the nutritionist who conducted the anthropometric and body composition evaluations.

In addition to HF conventional pharmacological treatment, an isocaloric salt-restricted diet was prescribed to patients in the intervention group (2000 to 2400 $\mathrm{mg} / \mathrm{d}$ of sodium) and composed as follow: of total calories, $50-55 \%$ of carbohydrates (with a preference for complex carbohydrates and fiber), $0,8 \mathrm{~g}$ of protein per $\mathrm{kg}$ body weight per day, $30-35 \%$ of total lipids $(<10 \%$ saturated, $10 \%$ polyunsaturated, $15 \%$ monounsaturated, and $<300 \mathrm{mg} / \mathrm{d}$ of cholesterol). Total fluids were limited to $1,5 \mathrm{~L} / \mathrm{d}$, including the water in food. These patients received written and oral instructions from the dietitian and were advised to avoid sodium-rich food, limit the intake of food with moderate amounts of sodium, and eat no more than one-fourth a teaspoon of salt per day. Adherence to diet was evaluated by a 24-hours food recall collected every 2 months, and suggestions and corrections were provided, when necessary.

Patients in the control group received conventional pharmacological treatment for $\mathrm{HF}$ as well as common dietary oral advisories by the cardiologist regarding decreased sodium and fluid intakes, as it is recommended by the guidelines $(5,6)$ for the evaluation and management of patients with HF.

Anthropometric variables, body composition, dietary intake, metabolic, and clinical evaluations were performed on all patients at baseline and 12 months.

\section{Measurements}

Anthropometry and body composition. Weight and height were measured according to the reference manual of anthropometric standardization (11), and all subjects wore little clothing and were barefoot. Body mass index was calculated by dividing total body weight (kilograms) by height squared (square meters). Body composition was evaluated with tetrapolar and multiplefrequencies equipment (BodyStat QuadScan 4000), and extracellular water (ECW) was obtained.

Dietary intake. Dietary intake data were obtained by a 3-day food record. Nutrients obtained from a 3-day average of food records were analyzed with a computerized nutrition database (SCVAN 1,0, 1993, Instituto Nacional de Ciencias Médicas y Nutrición SZ, Mexico City, Mexico), which contains the nutritional values of Mexican food. Missing foods were added by using the Mexican Food and Nutrient Values Tables (12). Sodium intake was evaluated by twenty-four-hour urine samples, assuming that 24-hour urinary sodium excretion is equivalent to approximately $86 \%$ of the daily sodium intake, as reported by Korhonen et al. (13).

Biochemical analysis. Fasting blood samples were analyzed for plasma concentrations of glucose, albumin, hemoglobin, hematocrit, triglycerides, total cholesterol, high-density lipoprotein cholesterol, and low-density lipoprotein cholesterol. Plasma glucose was enzymatically determined with the glucose oxidase technique, and plasma concentrations of total cholesterol and triglycerides were measured with an automated system (Synchron 
CX5, Beckman Instruments). High-density lipoprotein cholesterol was precipitated with phosphotungstic acid and $\mathrm{Mg} 2+$, and low-density lipoprotein cholesterol was calculated as follows: total cholesterol - (high-density lipoprotein cholesterol + triglycerides/5). We defined dyslipidemia as a total cholesterol level above $200 \mathrm{mg} /$ $\mathrm{dL}$, a low-density lipoprotein cholesterol level above 100 $\mathrm{mg} / \mathrm{dL}$, and/or a triglycerides level above $150 \mathrm{mg} / \mathrm{dL}$.

Clinical Data. Symptoms such as fatigue, dyspnea, edema, and functional class according the New York Heart Association (NYHA) (14) were evaluated during the medical interview. Functional capacity was measured in metabolic equivalents (METs, where one MET is 3,5 $\mathrm{mL} / \mathrm{kg}$ per min of oxygen consumption) with symptom-limited treadmill exercise testing, conducted according to modified Bruce protocol (15). Also, all patients underwent a transthoracic echocardiogram to determine ventricular function.

\section{Endpoints}

Primary endpoints (prognosis). Cardiovascular hospitalizations (HF decompensate, cardiac arrhythmias, acute pulmonary embolism, acute pulmonary edema, and acute coronary syndromes) and 12 months survival, were primary endpoints.

Secondary Endpoints. Decrease of symptoms (edema, dyspnea or fatigue) expressed as percentage of decrease at the end of the study respect to the baseline, and increase in physical effort achieved, were considered secondary endpoints.

\section{Statistic analysis}

All analyses were performed with commercially available software (SPSS 15,0 for Windows, SPSS, Inc., Chicago, IL, USA). Continuous variables are expressed as mean + standard deviation, and categorical variables are presented as relative frequencies. For the baseline comparison between the groups on continues variables independent-samples $\mathrm{t}$ was used and for categorical variables $\mathrm{X}^{2}$.

Changes observed at 12 months of follow-up on continuous variables were presented as percentages of change respect to the baseline. Percentages of change were compared between groups by Mann-Whitney U test. Changes on categorical variables into each group were evaluated by Mac-Nemar test. Kaplan-Meier survival analysis with Log rank significance test was also performed.

For the analysis of the study variables, excepting survival, patients that were lost to follow-up, for whom final measurements were not available, and those who failed in adherence to diet were not included. For the survival analysis, only non-adherence patients were eliminated.

\section{RESULTS}

Of the 203 patients included in the present study ( $\mathrm{IG}=84$ y $\mathrm{CG}=119$ ), ten were lost to follow-up, four died, and eight were eliminated from the intervention group due to non-adherence to the diet. In the control group, thirteen were lost to follow-up and 12 died (figure 1).

\section{Baseline}

Baseline characteristics by group are listed in table 1. Fatigue was more frequent in the IG and functional capacity achieved was worse for this same group. At the beginning of the study all patients were taking two or more of the following drugs administrated at high-dose according to patient tolerance: beta-blockers, angiotensin-converting enzyme inhibitors and/or angiotensin II receptor blockers, diuretics, digitalis, oral nitrates and aldosterone receptor antagonists.

For the evaluation of cardiac function patients were divided into systolic and diastolic heart failure groups. Among systolic heart failure patients it was observed a lower mean ejection fraction for the IG. There were not significant differences between groups in diastolic heart failure subjects (table 2).

Mean nutrient intake at baseline was similar between groups (data not shown).

\section{Follow-up}

At the end of the study, there were no significant differences in the anthropometric variables (weight and BMI) between the two groups, unlike body composition parameters, where the percentage change of extracellular water decreased in the intervention group and increased in the controls $(-1,4 \pm 5,0$ vs. $1,2 \pm 4,4 \%$; $=0,03)$. Regarding biochemical parameters, hematocrit showed a significant increase in the IG in comparison with a decrease in the $\mathrm{CG}(2,0+7,3$ vs. $-3,3+8,4 \% ; \mathrm{p}=0,04)$ (table 3$)$.

Mean changes in dietary intake between groups are shown in table 4. Calories consumption increased in both groups without significant differences between them, and total lipids intake diminished in the intervention group as much as in the control. However, dietary cholesterol consumption showed a significant difference between groups, with an important decrease in the intervention subjects in comparison with an increase in the controls. In addition, saturated fatty acids and fluids intakes decrease in the IG more than in the CG. Also, calcium consumption adjusted by caloric intake significantly decreased among intervention subjects in comparison with an increase in the controls. 
Mean sodium intake showed an increase in both groups at the end of the study, however, these data did not account for the salt used in cooking, which represents a major component of salt intake in this population. For that reason, urinary sodium excretion was determined and a significant difference between groups for the change percentage was observed $(-16,4 \pm 13,7$ vs. $8,8 \pm 46,5 \%$, $\mathrm{p}<0,05$, for IG and CG, respectively). The mean urinary sodium excretion at the end of the study corresponded to $1360 \pm 398 \mathrm{mg} / \mathrm{dL}$ in the IG and $2357 \pm 1202 \mathrm{mg} / \mathrm{dL}$ in the CG.

At the end of the study, decrease percentage of fatigue was significant and higher in the intervention $(52,9 \%, \mathrm{p}=0,02)$ that in the control group $(46,4 \%, \mathrm{p}=\mathrm{NS})$. Presence of edema decreased $68 \%$ in the IG and $40 \%$ in the CG; these differences were not statistically significant. Dyspnea did not show significant differences for any group.

In the IG, decrease in fatigue was concordant with the observed one in the METs of activity achieved. Mean change percentage for METs registered showed a trend to increase in the IG vs. CG $(39,6+60,0$ vs. $-7,9+34,7 \%$; $\mathrm{p}=0,08)$. NYHA functional class improved significantly in both groups at the end of the study.

\section{FIGURE 1}

Flow diagram for inclusion/exclusion criteria and follow-up of patients in both study groups.

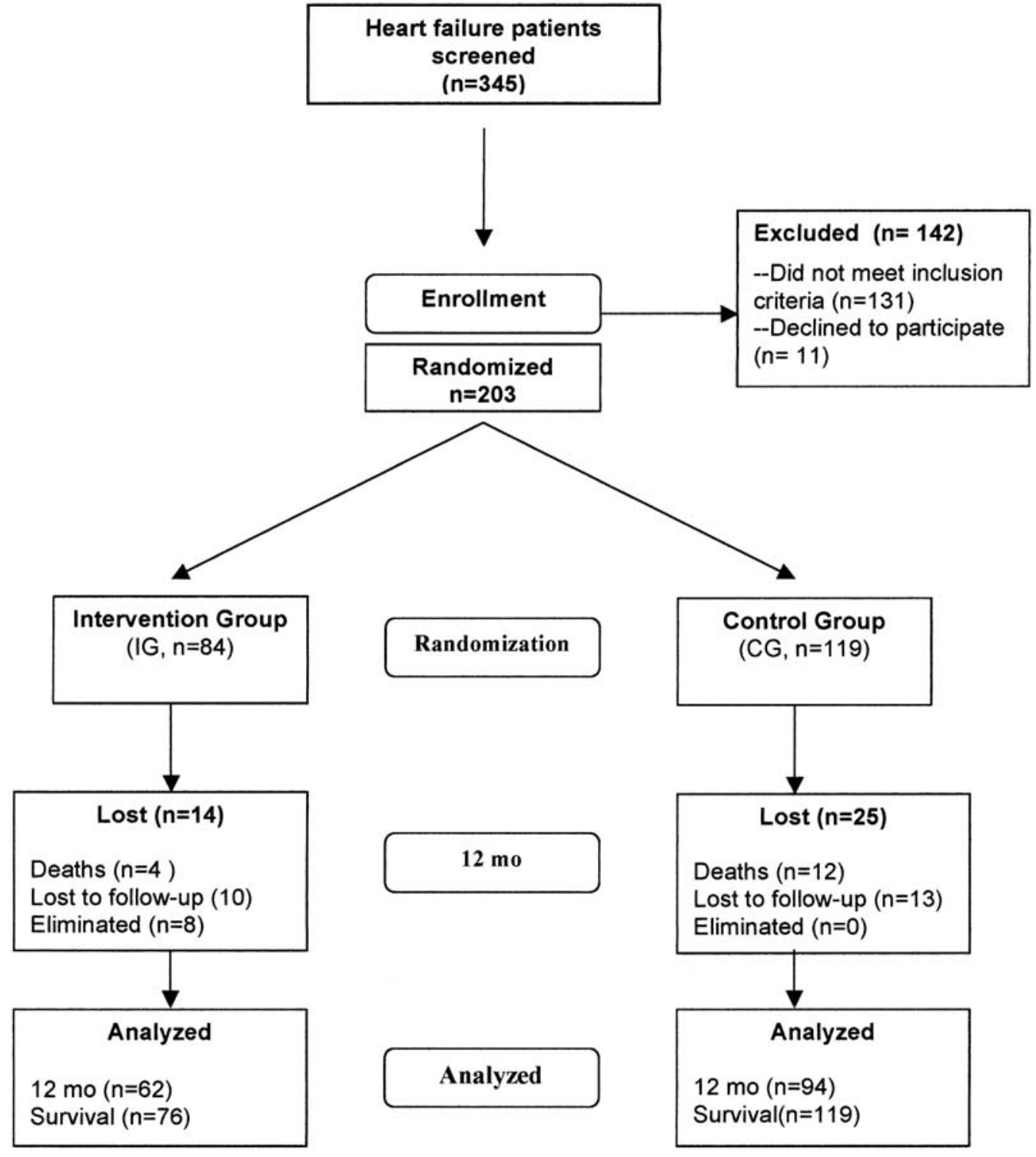




\section{TABLE 1}

\section{Baseline characteristics of patients by study group}

\begin{tabular}{|c|c|c|c|}
\hline & $\begin{array}{c}\text { Intervention } \\
\mathbf{n}=76\end{array}$ & $\begin{array}{l}\text { Control } \\
n=119\end{array}$ & Pvalue* \\
\hline $\operatorname{Men}(\%)$ & 54,4 & 57,1 & NS \\
\hline Age $(y)$ & $64,5+8,4$ & $62,4+9,6$ & NS \\
\hline Hypertension (\%) & 64,6 & 66,7 & NS \\
\hline Diabetes (\%) & 48,1 & 42,6 & NS \\
\hline Dyslipidemia (\%) & 83,6 & 83,0 & NS \\
\hline Systolic heart failure (\%) & 58,2 & 58,0 & NS \\
\hline Ischemic cardiomyopathy (\%) & 50,0 & 50,4 & NS \\
\hline \multicolumn{4}{|c|}{ Anthropometric and body composition } \\
\hline Weight (kg) & $72,4+25,4$ & $72,6+21,7$ & NS \\
\hline Height $(\mathrm{cm})$ & $157,2+9,8$ & $157,4+10,4$ & NS \\
\hline Body Mass Index (kg/m2) & $28,1+6,1$ & $28,7+6,8$ & NS \\
\hline Extracellular water (\%) & $23,3+2,9$ & $22,9+3,1$ & NS \\
\hline \multicolumn{4}{|l|}{ Metabolic } \\
\hline Albumin (g/dL) & $3,6+0,5$ & $3,8+0,5$ & NS \\
\hline Hemoglobin (mg/dL) & $14,5+1,8$ & $14,6+2,2$ & NS \\
\hline Hematocrit (\%) & $42,9+5,5$ & $43,7+6,6$ & NS \\
\hline Total Cholesterol (mg/dL) & $171,4+49,5$ & $181,9+45,9$ & NS \\
\hline LDL cholesterol (mg/dL) & $101,7+39,8$ & $110,1+32,1$ & NS \\
\hline HDL cholesterol (mg/dL) & $38,1+11,8$ & $40,1+11,6$ & NS \\
\hline Triglycerides (mg/dL) & $170,5+89,5$ & $171,7+99,4$ & NS \\
\hline Serum sodium $(\mathrm{mmol} / \mathrm{dL})$ & $136,9+3,2$ & $137,2+3,2$ & NS \\
\hline Glucose (mg/dL) & $120,3+41,5$ & $126,8+53,4$ & NS \\
\hline Urinary sodium (mg/dL) & $2084+774$ & $2114+836$ & NS \\
\hline \multicolumn{4}{|l|}{ Symptoms } \\
\hline Edema $(\%)$ & 44,7 & 37,8 & NS \\
\hline Dyspnea (\%) & 47,5 & 33,3 & NS \\
\hline Fatigue (\%) & 59,7 & 42,7 & 0,02 \\
\hline \multirow{3}{*}{$\begin{array}{ll}\text { NYHA functional class (\%) } & \text { I } \\
& \text { II } \\
& \text { III }\end{array}$} & 44,9 & 58,3 & \\
\hline & 39,7 & 28,7 & NS \\
\hline & 15,4 & 13,0 & \\
\hline Functional capacity (mets) & $4,1+1,8$ & $5,5+2,2$ & 0,02 \\
\hline \multicolumn{4}{|l|}{ Drugs } \\
\hline Beta-blockers (\%) & 78,5 & 80,7 & NS \\
\hline ACEI or ARB (\%) & 95,6 & 93,0 & NS \\
\hline Loop diuretics (\%) & 15,6 & 15,1 & NS \\
\hline Loop diuretics doses $(\mathrm{mg} / \mathrm{d})$ & $44,1 \pm 10,6$ & $41,7 \pm 15,13$ & NS \\
\hline
\end{tabular}


The impact of the diet on cardiac function was evaluated by heart failure group. In this sense, the improvement on dietary profile (specifically the decrease in sodium and fluids intakes) had an impact on cardiac function reflected as a statistically significant increase in the ejection fraction for the IG vs. CG, among systolic HF subjects (percentages of change, 49,6+53,5 vs. $5,0+19,8 \% ; \mathrm{p}=0,001)$. The other cardiac parameters did not show significant differences. Among diastolic HF subjects, there were no significant differences between study groups.

It is important to emphasize that HF medication was similar between groups during the follow-up (data not shown).

\section{Prognosis results}

Proportion of patients with at least one cardiovascular hospitalization during follow-up was lower in the IG vs. $C G(11,1$ vs. $15,7 \%$; $p=0,3)$; however, this difference was not statistically significant. In addition, survival showed a trend to be better among intervention patients, since one-year cumulative probability of survival among subjects with intervention was $93,7 \%$ vs. $88,1 \%$ in the CG (figure 2). Of the four deaths registered in the CG and of the 12 in the CG, 2 (50\%) and 8 (66.7\%) were cardiovascular deaths, respectively.

\section{DISCUSSION}

The present study showed the favorable influence of a nutritional intervention with restriction of sodium $(<2400 \mathrm{mg} / \mathrm{d})$ and liquid $(<1500 \mathrm{ml} / \mathrm{d})$ as part of nonpharmacological treatment in stable systolic and diastolic heart failure patient (NYHA I-III), with improvement in clinical status (decrease of fatigue and better functional capacity) and cardiac function (improved ejection fraction). Indeed, prognosis was better for patients receiving this nutritional intervention, although differences were not statistically significant. The lack of significance could be explained, in part, because of the few events (deaths) observed in both groups and its repercussion on statistical power.

At the end of the study, IG had a higher decrease in liquid intake. Also, urinary sodium excretion, that evaluates indirectly the dietary sodium consumption, showed a significant decrease in the IG vs. CG, obtaining a final mean sodium excretion of $1360 \mathrm{mg} / \mathrm{dL}$ for IG and $2357 \mathrm{mg} / \mathrm{dL}$ for CG; this suggest a sodium intake of $1581 \mathrm{mg} / \mathrm{d}$ and $2740 \mathrm{mg} / \mathrm{d}$, for each group respectively, considering that excretion represents approximately $86 \%$ of ingestion.

The sodium and fluid intake can greatly assist in the maintenance of volume balance in HF patients (16). This was confirmed in the present study through the decrease in urinary sodium and ECW and an increase in hematocrit, even without significant decrease in weight. Beich et al. (4) suggest that to optimize sodium consumption earlier in the course of the HF syndrome could prevent the cardio-renal syndrome, perhaps by limiting diuretic use which may avert the occurrence of this syndrome. Also, it is important to emphasize that findings in this study suggest that a routine body composition evaluation by the bioelectrical impedance method could be particularly useful to detect fluid overload in the early stages of fluid retention, before apparent edema

\section{TABLE 2}

\section{Echocardiographic characteristics by type of heart failure and study groups}

\begin{tabular}{|c|c|c|c|c|c|c|}
\hline & \multicolumn{3}{|c|}{$\begin{array}{l}\text { Systolic Heart Failure } \\
\qquad n=76\end{array}$} & \multicolumn{3}{|c|}{$\begin{array}{l}\text { Diastolic Heart Failure } \\
\qquad \mathbf{n}=119\end{array}$} \\
\hline & Intervention & Control & P value* & Intervention & Control & P value* \\
\hline LVEF (\%) & $29,7+9,9$ & $35,2+12,7$ & 0,02 & $57,6+14,5$ & $56,1+9,4$ & NS \\
\hline LVEDD (mm) & $52,7+9,4$ & $54,1+9,7$ & NS & $46,3+8,9$ & $47,4+7,6$ & NS \\
\hline LVESD (mm) & $43,1+10,6$ & $42,2+10,6$ & NS & $29,7+11,3$ & $30,4+7,0$ & NS \\
\hline $\mathrm{LAD}(\mathrm{mm})$ & $43,7+7,6$ & $44,4+9,0$ & NS & $46,5+6,1$ & $43,5+7,1$ & NS \\
\hline AoD (mm) & $31,1+4,6$ & $31,0+5,3$ & NS & $31,6+4,7$ & $31,9+5,1$ & NS \\
\hline
\end{tabular}


appears, and to allow the clinician to modify diuretics prescription, thereby avoiding functional deterioration, progression of structural abnormalities, and worsening the quality of life.

Likewise, in these study patients that received nutritional intervention additional to the significant decrease in ECW at the end of the follow-up, they also had a decrease in fatigue, corroborated by an increase in functional capacity (METs). These findings can be explained by Chomsky et al. study (17) which suggests that heart failure patients with volume overloud, even without clinical evidence (edema), frequently have higher intracardiac diastolic pressures, and that after removal of this subclinical fluid excess, exercise tolerance improves.

Although the positive results of the present study, other studies suggest that is possible that a strict low-

\section{TABLE 3}

\section{Mean anthropometric, body composition, and biochemical variables and magnitude of change from baseline to end of study}

\begin{tabular}{|c|c|c|c|c|c|c|c|}
\hline & \multicolumn{2}{|c|}{ Baseline } & \multicolumn{2}{|c|}{ End } & \multicolumn{2}{|c|}{$\%$ change } & $\begin{array}{l}P \text { for } \\
\% \text { change* }\end{array}$ \\
\hline & $\begin{array}{l}\text { Intervention } \\
\quad \mathrm{n}=62\end{array}$ & $\begin{array}{c}\text { Control } \\
\mathrm{n}=94\end{array}$ & $\begin{array}{c}\text { Intervention } \\
\quad \mathrm{n}=62\end{array}$ & $\begin{array}{c}\text { Control } \\
\mathrm{n}=94\end{array}$ & $\begin{array}{l}\text { Intervention } \\
\quad \mathrm{n}=62\end{array}$ & $\begin{array}{c}\text { Control } \\
\mathrm{n}=94\end{array}$ & \\
\hline $\begin{array}{l}\text { Weight } \\
(\mathrm{kg})\end{array}$ & $70,1+13,9$ & $71,9+18,8$ & $69,7+16,2$ & $72,8+20,1$ & $2,8+10,5$ & $0,4+6,4$ & NS \\
\hline $\begin{array}{l}\text { Body Mass Index } \\
\left(\mathrm{kg} / \mathrm{m}^{2}\right)\end{array}$ & $28,2+3,6$ & $28,7+6,8$ & $27,9+3,8$ & $28,7+6,7$ & $0,5+8,8$ & $0,7+6,1$ & NS \\
\hline $\begin{array}{l}\text { Extracellular water } \\
(\%)\end{array}$ & $23,2+2,1$ & $22,7+2,7$ & $22,6+1,8$ & $22,8+2,4$ & $-1,4+5,0$ & $1,2+4,5$ & 0,03 \\
\hline $\begin{array}{l}\text { Albumin } \\
(\mathrm{g} / \mathrm{dl})\end{array}$ & $4,0+0,4$ & $3,9+0,4$ & $3,8+0,2$ & $3,7+0,3$ & $3,2+12,1$ & $-0,8+8,5$ & NS \\
\hline $\begin{array}{l}\text { Hemoglobin } \\
(\mathrm{mg} / \mathrm{dl})\end{array}$ & $14,3+1,3$ & $14,6+1,7$ & $14,5+1,5$ & $14,5+2,0$ & $3,4+7,6$ & $-1,2+8,6$ & NS \\
\hline $\begin{array}{l}\text { Hematocrit } \\
(\%)\end{array}$ & $42,0+3,7$ & $43,9+5,0$ & $42,5+3,9$ & $42,9+6,4$ & $2,0+7,3$ & $-3,3+8,4$ & 0,04 \\
\hline $\begin{array}{l}\text { Total cholesterol } \\
(\mathrm{mg} / \mathrm{dL})\end{array}$ & $178,8+45,4$ & $185,0+46,7$ & $175,5+46,5$ & $178,9+41,5$ & $-0,7+19,6$ & $-4,2+22,8$ & NS \\
\hline $\begin{array}{l}\text { LDL cholesterol } \\
(\mathrm{mg} / \mathrm{dL})\end{array}$ & $102,4+38,7$ & $117,3+32,5$ & $106,9+38,8$ & $110,2+39,3$ & $-6,3+12,1$ & $-5,6+31,6$ & NS \\
\hline $\begin{array}{l}\text { HDL cholesterol } \\
(\mathrm{mg} / \mathrm{dL})\end{array}$ & $39,9+11,0$ & $40,2+10,9$ & $38,1+8,5$ & $35,4+8,0$ & $-2,6+19,4$ & $-6,5+17,6$ & NS \\
\hline $\begin{array}{l}\text { Triglycerides } \\
(\mathrm{mg} / \mathrm{dL})\end{array}$ & $195,8+99,5$ & $172,9+98,7$ & $173,9+94,8$ & $190,3+107,8$ & $6,4+36,5$ & $13,7+53,2$ & NS \\
\hline $\begin{array}{l}\text { Serum sodium } \\
(\mathrm{mmol} / \mathrm{dL})\end{array}$ & $135,6+3,9$ & $137,4+3,3$ & $136,0+2,9$ & $137,8+2,5$ & $0,8+2,3$ & $0,7+2,9$ & NS \\
\hline $\begin{array}{l}\text { Glucose } \\
(\mathrm{mg} / \mathrm{dL})\end{array}$ & $125,9+36,8$ & $124,4+45,6$ & $149,4+76,2$ & $109,5+24,2$ & $9,7+31,3$ & $-0,1+13,7$ & NS \\
\hline
\end{tabular}


sodium diet is not warranted in euvolemic compensated HF patients who are on appropriate evidence-based therapy (4). In one of these studies, Alvelos et al. (7) attempted to determine whether sodium restriction was therapeutic in patients assessed to have mild-to moderate compensated systolic HF. For this purpose, 24 patients with mild-to-moderate chronic HF were studied, 12 consumed $100 \mathrm{mmol}(2300 \mathrm{mg})$ sodium daily and 12 continued their usual-salt diet (controls) where sodium intake was not restricted or quantified, during a 15-day

\section{TABLE 4}

Mean nutrient intake and magnitude of change from baseline to end of study.

\begin{tabular}{|c|c|c|c|c|c|c|c|}
\hline & \multicolumn{2}{|c|}{ Baseline } & \multicolumn{2}{|c|}{ End } & \multicolumn{2}{|c|}{$\%$ change } & $\begin{array}{c}\mathbf{P} \text { for } \\
\% \text { change* }\end{array}$ \\
\hline & $\begin{array}{c}\text { Intervention } \\
\mathrm{n}=62\end{array}$ & $\begin{array}{c}\text { Control } \\
n=94\end{array}$ & $\begin{array}{c}\text { Intervention } \\
\mathrm{n}=62\end{array}$ & $\begin{array}{c}\text { Control } \\
n=94\end{array}$ & $\begin{array}{c}\text { Intervention } \\
n=62\end{array}$ & $\begin{array}{c}\text { Control } \\
n=94\end{array}$ & \\
\hline Fiber (g) & $8,4+5,0$ & $8,9+5,1$ & $10,8+6,9$ & $12,3+7,7$ & $76,6+130,5$ & $41,1+106,4$ & NS \\
\hline Energy (kcal) & $1882+606$ & $1660+477$ & $1636+699$ & $2119+954$ & $3,0+59,1$ & $9,0+29,3$ & NS \\
\hline \multicolumn{8}{|l|}{ Energy from: } \\
\hline Carbohydrate (\%) & $53,9+12$ & $53,4+6,6$ & $54,4+7,3$ & $54,9+8,2$ & $0,1+18,0$ & $6,1+18,4$ & NS \\
\hline Protein $(\%)$ & $15,3+2,6$ & $14,9+2,5$ & $16,6+2,8$ & $15,1+3,1$ & $0,5+19,8$ & $3,1+29,8$ & NS \\
\hline Total fat (\%) & $31,6+10,0$ & $32,9+6,6$ & $30,8+7,2$ & $31,8+9,6$ & $-1,4+24,6$ & $-1,4+34,1$ & NS \\
\hline $\begin{array}{l}\text { Saturate } \\
\text { fatty acids }(\%)\end{array}$ & $8,7+4,8$ & $7,6+2,7$ & $7,3+3,3$ & $7,4+2,9$ & $-16,1+19,8$ & $-2,8+32,9$ & 0,04 \\
\hline $\begin{array}{l}\text { Monounsaturated } \\
\text { fatty acids }(\%)\end{array}$ & $9,2+3,3$ & $9,2+2,9$ & $8,5+3,9$ & $8,9+3,5$ & $9,3+54,5$ & $-11,7+37,3$ & NS \\
\hline $\begin{array}{l}\text { Polyunsaturated } \\
\text { fatty acids (\%) }\end{array}$ & $5,3+1,6$ & $5,7+2,0$ & $5,8+2,9$ & $6,9+3,2$ & $60,5+96,8$ & $10,3+58,3$ & NS \\
\hline Cholesterol (mg) & $215,9+128,9$ & $217,9+184,4$ & $142,8+101,7$ & $188,8+128,1$ & $-31,2+57,5$ & $7,5+73,4$ & 0,03 \\
\hline $\begin{array}{l}\text { Calcium } \\
(\mathrm{mg} / 1000 \mathrm{kcal})\end{array}$ & $572,2+285,6$ & $474,9+135,1$ & $572,0+302,1$ & $480,7+315,0$ & $-27,8+44,8$ & $10,5+52,3$ & 0,03 \\
\hline $\begin{array}{l}\text { Iron } \\
(\mathrm{mg} / 1000 \mathrm{kcal})\end{array}$ & $6,9+1,9$ & $6,7+1,7$ & $6,5+2,5$ & $8,1+5,3$ & $-18,8+40,6$ & $8,9+45,7$ & NS \\
\hline $\begin{array}{l}\text { Magnesium } \\
(\mathrm{mg} / 1000 \mathrm{kcal})\end{array}$ & $90,0+45,0$ & $89,4+39,1$ & $114,5+53,7$ & $110,2+111,9$ & $56,1+88,9$ & $31,1+72,4$ & NS \\
\hline $\begin{array}{l}\text { Sodium } \\
(\mathrm{mg} / 1000 \mathrm{kcal}) \dagger\end{array}$ & $496,8+396,2$ & $366,1+233,6$ & $543,5+519,1$ & $450,7+581,3$ & $22,7+95,0$ & $22,2+92,9$ & NS \\
\hline $\begin{array}{l}\text { Potassium } \\
(\mathrm{mg} / 1000 \mathrm{kcal})\end{array}$ & $1066,3+491,3$ & $867,8+299,7$ & $1306+554$ & $1155+1002$ & $57,9+86,5$ & $23,1+47,1$ & NS \\
\hline Fluids $\ddagger$ & $1895,1+847,2$ & $1595,9+559,0$ & $1525+511$ & $1461+468$ & $-20,3+29,6$ & $-8,6+35,5$ & 0,02 \\
\hline $\begin{array}{l}\dagger \text { Excluding salt used in } \\
\ddagger \text { Including water contai } \\
\text { NS, not significant. } \\
\text { * By Mann-Withney U t }\end{array}$ & $\begin{array}{l}\text { king. } \\
\text { in foods. }\end{array}$ & & & & & & \\
\hline
\end{tabular}


period. The findings were that the lower-sodium-intake group had lower blood pressure and urinary sodium excretion, and more weight loss (fluid loss) than the normal sodium group. They also had lower B-type natriuretic peptide (BNP), an indirect marker of heart function, which increases with higher left ventricular volume and pressure. However, volume depletion induced by the low-sodium diet led to an activation of the sympathetic nervous and renin-angiotensin-aldosterone systems. Dopamine synthesis was increased probably as a counter-regulatory mechanism. The activation of these vasoconstrictors, antinatriuretic, and antidiuretic systems may had induced a reduction in renal blood flow leading to an increase in renal sodium and water reabsorption and overall worsening of the neurohumoral steady state. It is important to mention that all of these euvolemic patients were taking furosemide (mean dose 86,7 $\pm 11,9 \mathrm{mg} / \mathrm{d}$ ).

On the other side, Paterna et al. (8) compared hospital readmission rates for HF patients based on consumption of a normal-sodium diet $(120 \mathrm{mmol}$ or
$2760 \mathrm{mg}$ daily) or a "low-sodium" diet ( $80 \mathrm{mmol}$ or $1840 \mathrm{mg}$ daily). The study consisted of 232 compensated HF patients divided into 2 groups based on prescribed diet, all taking high-dose oral furosemide $(250-500 \mathrm{mg}$, twice a day) and restricting fluid to $1000 \mathrm{ml}$ per day. The normal-sodium group had a lower incidence of hospital readmissions and mortality compared with the low-sodium group. Serum aldosterone and renin levels were significantly higher in the "low-sodium" group at follow-up, indicating an increase in neurohormonal activation. However, BNP was significantly lower at 90 and 180 days of follow-up in the normal-sodium group.

The differences between the findings of those studies and ours, regarding fluid balance perhaps are due to the high doses of loop diuretics used by them. So that, as Beich and Yancy stated (4), it would be necessary an individualized sodium prescription calculated based on such factors as disease risk, activity level, energy needs, renal and cardiac function, volume status, medication effects, fluid intake and output.

\section{FIGURE 2}

One year cumulative survivel for heart failure by study group.

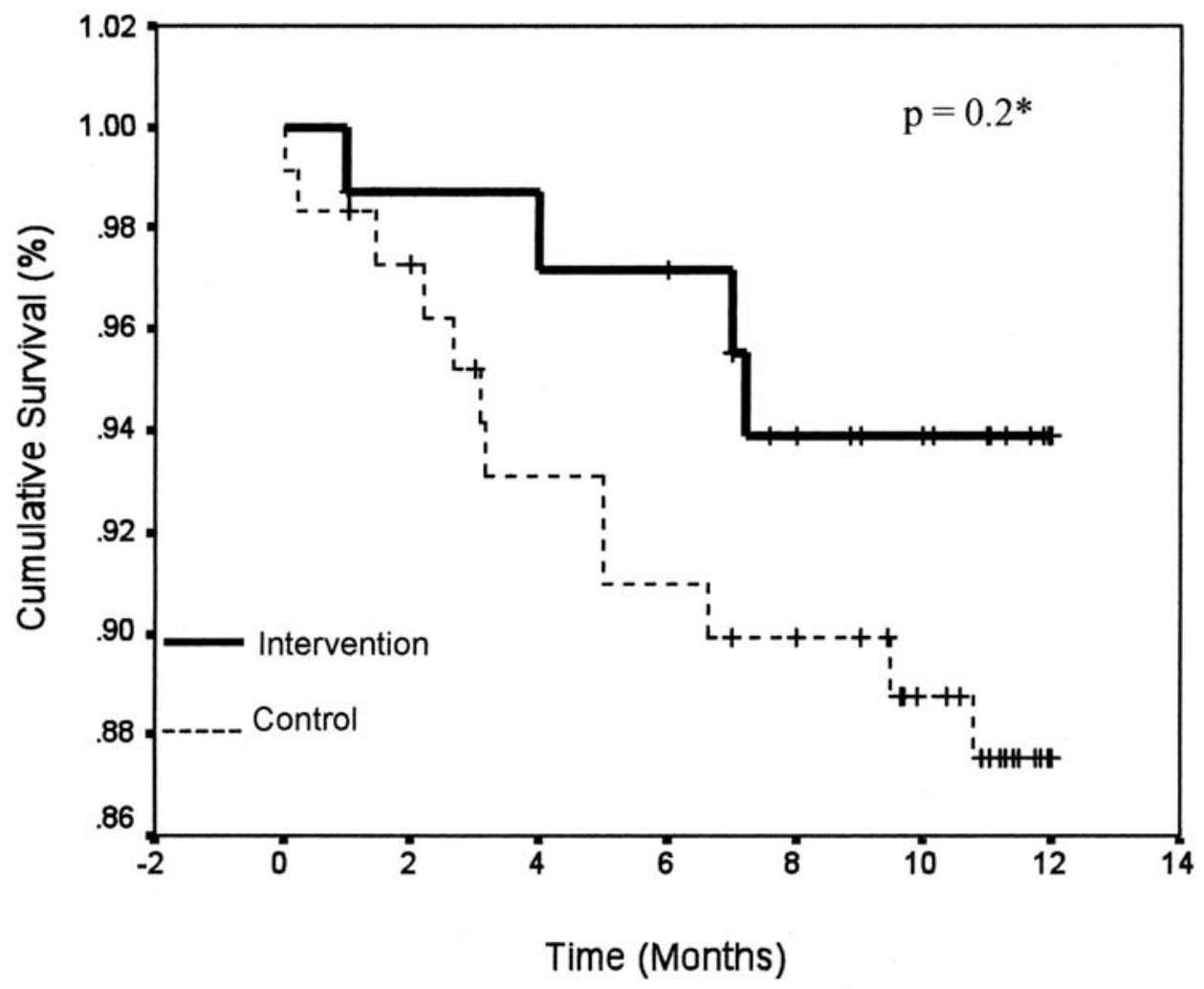

* By Log rank test 
The intervention group had better survival and less cardiovascular hospitalizations compared with the control group. Although these differences were not statistically significant, the significant increase of ejection fraction among patients with systolic heart failure in the IG could suggests a better prognosis in these patients, because ejection fraction has been recognized as one of the most important independent prognostic marker in $\operatorname{HF}(16,18)$.

Additional to the decrease in cholesterol and saturated fatty acids intake in the IG, also it was found a reduction in calcium intake. This could be in accordance with result of the study of Arcand et al. (19), they found in stable heart failure patients inadequacies of certain vitamins and minerals like calcium, magnesium, folate, and vitamins $\mathrm{D}$ and $\mathrm{E}$, related to a not excessive sodium intake. These findings highlight the importance of diet beyond that of sodium restriction.

\section{STUDY LIMITATIONS}

This study has two important limitations: first, patients in NYHA functional class IV were not included, in whom the prognosis is different and the effect of the nutritional intervention could be different; and second, there were lost of cases during follow-up and the statistical analysis included only the patients that had adherence to diet. Thus, the applicability of our findings to other patients with heart failure requires further studies.

\section{CONCLUSION}

In conclusion, a nutritional intervention with intake restriction of sodium ( $<2400 \mathrm{mg} /$ day) and fluid less than $1500 \mathrm{ml} /$ day had positive effects in stable systolic and diastolic heart failure patients after one year of followup, like decrease in extracellular water and fatigue, as well as an increase in hematocrit. Also, in systolic heart failure patients, left ventricular function improved even the better prognosis was not statically significant.

\section{RESUMEN}

Objetivo: Evaluar el efecto de una intervención nutricional sobre el estado clínico y el pronóstico de pacientes con insuficiencia cardiaca (IC). Métodos: Doscientos tres pacientes con IC fueron aleatorizados al grupo con intervención (GI, n=84) o al control (GC, $\mathrm{n}=119$ ) y seguidos por 12 meses. El GI recibió una dieta con restricción de sodio (2000 a $2400 \mathrm{mg} / \mathrm{d}$ ) y líquidos $(<1500 \mathrm{ml} / \mathrm{d})$ y el GC recomendaciones nutricionales generales. Se evaluó la composición corporal, el estado clínico, hospitalizaciones y sobrevida. Resultados: Al término del seguimiento, la excreción urinaria de sodio disminuyó $16,4 \%$ en el GI vs. un aumento de $8,8 \%$ en el
$\mathrm{GC}(\mathrm{p}<0,05)$. El agua extracellular disminuyó $1,4 \%$ en el GI vs. $1,2 \%$ de aumento en el GC ( $\mathrm{p}=0,03)$. Asimismo, el porcentaje de reducción de fatiga fue significativo para el GI, no así para el GC; también se observó, entre los pacientes con IC sistólica, un aumento significativamente mayor en la fracción de expulsión para el GI vs. CG $(49,6 \%$ vs. $5,0 \%, p=0,001)$. El número de hospitalizaciones y el tiempo de sobrevida tuvieron una tendencia a ser mejor en el GI. Conclusión: Una intervención nutricional con restricción de sodio y líquidos mostró tener un impacto favorable en el estado clínico de pacientes con IC.

Palabras clave: insuficiencia cardiaca; intervención nutricional; composición corporal; sobrevida; agua extracelular.

Dirigir la correspondencia a:

Dra.

Lilia Castillo Martínez

Providencia 1218-A-408, Col del Valle

CP: 03100, México D. F., México

e-mail: caml1225@yahoo.com

\section{BIBLIOGRAFÍA}

1. Dracup K, Barker DW, Dunbar SB, Dacey RA, Brooks NH, Johnson JC et al. Management of heart failure: II. Counselling education, and lifestyle modification. JAMA 1994;272(18):1442-46.

2. Uretsky BF, Pina I, Quigg RJ, Brill JV, MacInerney EJ, Mintzer R et al. Beyond drug therapy: nonpharmacologic care of the patient with advanced heart failure. Am Heart J 1998;135:5264-84.

3. Grady K, Dracup K, Kennedy G, Moser D, Piano $\mathrm{M}$, Warner $\mathrm{L}$ et al. Team management of patients with heart failure. A statement for healthcare professionals from the Cardiovascular Nursing Council of the American Heart Association. Circulation 2000;102:2443-56.

4. Beich KR, Yancy C. The heart failure and sodium restriction controversy: challenging conventional practice. Nutr Clin Pract 2008;23:477-86.

5. ACC/AHA 2005 Guideline update for the diagnosis and management of chronic heart failure in the adult. A report of the American College of Cardiology/American Heart Association task force on practice guidelines (writing committee to update the 2001 guidelines for the evaluation and management of heart failure): Developed in collaboration with the American College of Chest Physicians and the International Society for Heart and Lung Transplantation: Endorsed by the Heart Rhythm Society. Circulation 2005;112:e154-e235. 
6. ESC Guidelines for the diagnosis and treatment of acute and chronic heart failure 2008: the Task Force for the Diagnosis and Treatment of Acute and Chronic Heart Failure 2008 of the European Society of Cardiology. Developed in collaboration with the Heart Failure Association of the ESC (HFA) and endorsed by the European Society of Intensive Care Medicine (ESICM). Eur Heart J 2008;29(19):2388-442.

7. Alvelos M, Ferreira A, Bettencourt $P$, Serrão $P$, Pestana M, Cerqueira M et al. The effect of dietary sodium restriction on neurohumoral activity and renal dopaminergic response in patients with heart failure. Eur J Heart Fail 2004;6:593-99.

8. Paterna S, Gaspare P, Fasullo S, Sarullo FM, Di Pasquale P. Normal-sodium diet compared with low-sodium diet in compensated congestive heart failure: is sodium an old enemy or a new friend? Clin Sci 2008;114:221-30.

9. Colín E, Castillo L, Orea A, Rebollar V, Narváez $\mathrm{R}$, Asensio E. Effects of a nutritional intervention on body composition, clinical status and quality of life in patients with heart failure. Nutrition 2004;20(10):890-95.

10. Travers B, O'Loughlin C, Murphy NF, Ryder M, Conlon C, Ledwidge $\mathrm{M}$ et al. Fluid restriction in the management of decompensated heart failure: no impact on time to clinical stability. J Card Fail 2007;13(2):128-32.

11. Lohman TG, Roche AF, Martorell R. Anthropometric standardization reference manual, Abridged edition. Champaign, IL: Human Kinetics Books, 1991.

12. Chávez M, Hernández M, Roldán J. Tabla de Uso
Práctico del Valor Nutritivo de los Alimentos de Mayor Consumo en México. México: Comisión Nacional de Alimentación. Instituto Nacional de la Nutrición Salvador Zubirán; 1992.

13. Korhonen MH, Järvinen R, Sarkkinen ES, Uusitupa M. Effects of a salt-restricted diet on the intake of other nutrients. Am J Clin Nutr 2000;72:414-20.

14. New York Heart Association. Disease of the heart and blood vessels. Nomenclature and criteria for diagnosis, 6th ed. Boston: Little, Brown, 1964, p. 114.

15. Bruce RA. Excercise testing of patients with coronary heart disease. Ann Clin Res 1974;3:323-30.

16. 2009 focused update: ACCF/AHA Guidelines for the Diagnosis and Management of Heart Failure in Adults: a report of the American College of Cardiology Foundation/American Heart Association Task Force on Practice Guidelines: developed in collaboration with the International Society for Heart and Lung Transplantation. Circulation 2009;119(14):1977-2016.

17. Chomsky DB, Lang CC, Rayos G, Wilson JR. Treatment of subclinical fluid retention in patients with symptomatic heart failure: effect on exercise performance. J Heart Lung Transplant 1997;16:846-53.

18. Curtis JP, Sokol SI, Wang Y, Rathore SS, Ko DT, Jadbabaie $\mathrm{F}$ et al. The association of left ventricular ejection fraction, mortality, and cause of death in stable outpatients with heart failure. J Am Coll Cardiol 2003;42:736-42.

19. Arcand J, Floras V, Ahmed M, Al-Hesayen A, Ivanov J, Allard JP et al. Nutrition inadequacies in patients with stable heart failure. J Am Diet Assoc 2009;109:1909-13. 